\title{
Original Unit or Value of Reported Test Result
}

National Cancer Institute

\section{Source}

National Cancer Institute. Original Unit or Value of Reported Test Result. NCI Thesaurus.

Code $C 70770$.

A unit of measure or value in which the outcome of the observation was originally reported. 